\title{
How does cell volume influence the total light absorption efficiency of a mixed population of dinoflagellates with similar cell shapes and pigment compositions?
}

\author{
Chieko Dairiki ${ }^{1}$, Shozo Motokawa ${ }^{1,2}$, Ai Murata ${ }^{1} \&$ Satoru Taguchi $^{1,3, *}$ \\ ${ }^{1}$ Soka University, Hachioji, Tokyo, Japan \\ ${ }^{2}$ Japan Agricultural Frontier Development Organization, Tokyo, Japan \\ ${ }^{3}$ National Institute of Polar Research, Tachikawa, Tokyo, Japan
}

Received 2 January 2020; Accepted 15 May 2020 Responsible Editor: Toshiya Katano

doi: $10.3800 /$ pbr. 15.250

\begin{abstract}
In vivo absorption spectra and spectrally reconstructed absorption spectra from HPLC-determined pigment concentrations were obtained and compared for five different mixtures of two dinoflagellates (large cells, Prorocentrum micans and small cells, Prorocentrum minimum) with similar cell shapes and pigment compositions but significant differences in pigment contents and cell volume. Although the large cells contained 4-fold higher chlorophyll $a$ content than the small cells, the observed intracellular chl $a$ contents per unit cell volume $\left(C_{\mathrm{i}}\right)$ increased with decreasing cell volume. Exponentially grown cells with the abovementioned characteristics were prepared for use in mixing experiments with $0,25,50,75$, and $100 \%$ of $P$. minimum and vice versa for P. micans. The in vivo absorption values determined at nine wavelengths $(412,440,480,510,532,555,650,676$, and $700 \mathrm{~nm})$ were significantly associated with the biomass with respect to either cell volume or chl $a$ concentration and were inversely correlated with $C_{\mathrm{i}}(p<0.01)$. The observed package effect $\left[Q_{\mathrm{a}}^{*}(\lambda)\right]$ indicated an overestimation of absorption spectra at all wavelengths by reconstruction. The fractional reduction of pigment absorption due to $Q_{\mathrm{a}}^{*}(\lambda)$ was wavelength dependent regardless of the mixing ratio of the two populations. The results showed that the product of equivalent spherical diameter and $C_{\mathrm{i}}$ should be considered for quantitative studies of $Q_{\mathrm{a}}^{*}(\lambda)$ in various chromatic-adapted species in cultures as well as in coastal waters.
\end{abstract}

Key words: absorption efficiency, chlorophyll $a$, package effect, reconstructed absorption spectra

\section{Introduction}

Photosynthetically active radiation is mostly absorbed by primary producers in the ocean ecosystem. Global marine primary production is estimated from the observation of field measurements and of ocean color data generated via remote sensing from satellites (Longhurst et al. 1995). While classical field measurements are too scarce to provide information on global change, remote sensing from satellites can continuously provide information temporally and spatially over a wide area. Satellite remote sensing techniques have been intensively investigated to develop methods for estimating global marine primary production (McClain et al. 2003).

To estimate primary production in the ocean, multiple

\footnotetext{
*Corresponding author: Satoru Taguchi; E-mail, satoru.sio@gmail.com
}

bio-optical models have been developed (Siegel et al. 1989, Behrenfeld \& Falkowski 1997), most of which are dependent on the light absorption characteristics of surface water, among which the chl $a$ specific absorption coefficient $\left(a_{\mathrm{ph}}^{*}\right)$ of phytoplankton is primarily considered (Bricaud \& Stramski 1990, Sosik \& Mitchell 1991, Babin et al. 1993). For laboratory cultures, a wide range of absorption spectra data has been accumulated for a large diversity of species (Sathyendranath et al. 1987, Bricaud et al. 1988, Berner et al. 1989, Nelson \& Prezelin 1990, Schofield et al. 1991, Finkel 2001, Fujiki \& Taguchi 2002, Leong \& Taguchi 2006). Variability in the $a_{\mathrm{ph}}^{*}$ is primarily governed by (1) pigment composition, (2) pigment concentration, and (3) cell volume (e.g., Sathyendranath et al. 1987). The changes in pigment composition influence the spectral characterization of $a_{\mathrm{ph}}^{*}$ (Sathyendranath et al. 1987). Increasing pigment concentration results in a decrease in $a_{\mathrm{ph}}^{*}$ (Kirk 1994, Lutz et al. 2001), while an increase in cell 
volume results in a decreased $a_{\mathrm{ph}}^{*}$ (Finkel 2001, Fujiki \& Taguchi 2002). Variation in cell volume is also caused by environmental factors such as irradiance and nutrient supply (Fujiki \& Taguchi 2002). In the ocean, natural phytoplankton assemblages are composed of a variety of species that have remarkable differences in pigment composition, concentration, and cell size. The results of field studies have suggested that variation in $a_{\mathrm{ph}}^{*}$ is caused by absorption properties within phytoplankton assemblages (Yentsch 1989). The dominant cell size and taxonomic group can govern the absorption spectra of natural phytoplankton assemblages (e.g., Ciotti et al. 2002). Variations in the absorption of phytoplankton assemblages with variable cell sizes have been demonstrated with a model (Morel \& Bricaud 1981), which has shown that $a_{\mathrm{ph}}^{*}$ decreases exponentially with increasing mean cell size in phytoplankton assemblages.

When cells with various cell volumes co-exist and are well mixed, the effect of cell volume on $a_{\mathrm{ph}}^{*}$ can provide information regarding the light absorption of phytoplankton assemblages, particularly at high concentrations. By using species within the same genus with a similar pigment composition, the influence of cell volume can be solely resolved for the package effect. In the field, a measurable package effect (Berner et al. 1989) was principally observed in samples taken from the subsurface chl $a$ maximum layer and in association with populations of large diatoms or dense concentrations of prymnesiophytes as described by Nelson et al. (1993). A similar package effect can be observed in dinoflagellates. Prorocentrum minimum (Pavillard) Schiller and Prorocentrum micans Ehreberg are primarily observed in coastal waters in temperate and tropical regions (Kimor et al. 1985, Smayda 1990, Grzebyk et al. 1997). These dinoflagellates bloom together and are consistently present in late summer and fall (Horner 2002, Kraberg et al. 2010). To describe the ecological

Table 1. Definition of symbols and abbreviations used in text.

\begin{tabular}{|c|c|}
\hline$a_{\mathrm{d}}(\lambda)$ & absorption coefficient of methanol-extracted particles $\left(\mathrm{m}^{-1}\right)$ \\
\hline$a_{\mathrm{p}}(\lambda)$ & absorption coefficient of particles $\left(\mathrm{m}^{-1}\right)$ \\
\hline$a_{\mathrm{ph}}(\lambda)$ & absorption coefficient of cells $\left(\mathrm{m}^{-1}\right)$ \\
\hline$a_{\mathrm{ph}}^{\prime}(\lambda)$ & absorption coefficient of cells reconstructed by the method proposed by Bidigare et al. (1990) $\left(\mathrm{m}^{-1}\right)$ \\
\hline$a_{\mathrm{ph}}^{*}(\lambda)$ & absorption coefficient of total cellular chl $a\left(\mathrm{~m}^{2}[\mathrm{mg} \mathrm{chl} a]^{-1}\right)$ \\
\hline $\bar{a}_{\mathrm{ph}}^{*}(\lambda)$ & spectral average of the chl $a$ specific absorption coefficient \\
\hline$a_{\min }^{*}(\lambda)$ & absorption coefficient of cellular chl $a$ of Prorocentrum minimum $\left(\mathrm{m}^{2}[\mathrm{mg} \mathrm{chl} a]^{-1}\right)$ \\
\hline$a_{\text {mic }}^{*}(\lambda)$ & absorption coefficient of cellular chl $a$ of Prorocentrum micans, $\left(\mathrm{m}^{2}[\mathrm{mg} \mathrm{chl} a]^{-1}\right)$ \\
\hline$\beta$-caro & $\beta$-carotene \\
\hline $\operatorname{chl} a$ & chlorophyll $a$ \\
\hline $\operatorname{chl} c$ & chlorophyll $c$ \\
\hline$C_{\mathrm{i}}$ & intracellular $i$ th pigment content $\left(\mathrm{kg} \mathrm{m}^{-3}\right)$ \\
\hline$C_{\min }$ & chlorophyll $a$ concentration of Prorocentrum minimum $\left(\mathrm{mg} \mathrm{m}^{-3}\right)$ \\
\hline$C_{\text {mic }}$ & chlorophyll $a$ concentration of Prorocentrum micans $\left(\mathrm{mg} \mathrm{m}^{-3}\right)$ \\
\hline$C_{\mathrm{t}}$ & intracellular total pigment content $\left(\mathrm{kg} \mathrm{m}^{-3}\right)$ \\
\hline DD & diatoxanthin \\
\hline DT & diatoxanthin \\
\hline ESD & equivalent spherical diameter $(\mathrm{m})$ \\
\hline$h$ & height $(\mathrm{m})$ \\
\hline$l$ & length $(\mathrm{m})$ \\
\hline$\mu$ & growth rate $\left(\mathrm{d}^{-1}\right)$ \\
\hline$N$ & cell density \\
\hline$N_{\mathrm{t}}$ & cell density in cells $\mathrm{mL}^{-1}$ at the beginning $\left(t_{0}\right)$ of the exponential phase \\
\hline$N_{0}$ & cell density in cells $\mathrm{mL}^{-1}$ at the end $\left(t_{1}\right)$ of the exponential phase \\
\hline$O D_{\mathrm{s}}(\lambda)$ & optical density of particles in suspension $\left(\mathrm{m}^{-1}\right)$ \\
\hline$O D_{\mathrm{f}}(\lambda)$ & optical density of filtered total particles $\left(\mathrm{m}^{-1}\right)$ \\
\hline perid & peridinin \\
\hline$Q_{\mathrm{a}}(\lambda)$ & cell absorption efficiency (Bricaud et al. 1983) \\
\hline$Q_{\mathrm{a}}^{*}(\lambda)$ & package effect \\
\hline$Q_{\mathrm{a}}^{\prime}(\lambda)$ & specific absorption efficiency (Morel and Bricaud 1981) \\
\hline$\rho^{\prime}(\lambda)$ & absorption index, product of $a_{\mathrm{ph}}(\lambda)$ and $d$ \\
\hline$S$ & filtered clearance area $\left(\mathrm{m}^{2}\right)$ \\
\hline$V$ & filtered volume $\left(\mathrm{m}^{3}\right)$ \\
\hline$w$ & width $(\mathrm{m})$ \\
\hline
\end{tabular}


significance of both species, a determination of their biooptical properties may be useful to divide them into groups of two sizes as discussed by Devred et al. (2006).

The objective of this study was: (1) to compare the effect of cell volume on in vivo absorption spectra $\left[a_{\mathrm{ph}}(\lambda)\right]$ and spectrally reconstructed in vivo absorption spectra $\left[a_{\mathrm{ph}}^{\prime}(\lambda)\right]$ based on observations of different mixing ratios of the dinoflagellates $P$. micans and $P$. minimum, which have different cell volumes but similar cell shapes and pigment compositions under similar culture conditions; and (2) to assess the impact of variability in the package effect $\left[Q_{\mathrm{a}}^{*}(\lambda)\right]$ on the total cellular absorption spectra.

\section{Materials and Methods}

\section{Strain and Pre-cultures}

The Dinophyceae Prorocentrum micans (NIES-218) and Prorocentrum minimum (NIES-237) were obtained from the microbial culture collection at the National Institute for Environmental Study (NIES), Japan. These species were maintained at $20^{\circ} \mathrm{C}$ and a salinity 35 in enriched $\mathrm{f} / 2$ medium (Guillard \& Ryther 1962) without silicate using aged filtered sea water collected from Manazuru Bay, Japan. An irradiance of $600 \mu \mathrm{mol}$ photons $\mathrm{m}^{-2} \mathrm{~s}^{-1}$ was provided for growth using cool fluorescent tubes on a $12 \mathrm{~h}$ light: $12 \mathrm{~h}$ dark cycle. Cells were preconditioned in a semi-continuous culture by being inoculated into daughter cultures for three growth cycles every three days to acclimate the cells to the growth conditions. The inoculation volume of $P$. micans and $P$. minimum was determined from the initial cell density, approximately 2000 and 2500 cells $\mathrm{mL}^{-1}$, respectively.

\section{Experimental design}

Prorocentrum micans and Prorocentrum minimum were grown for 7 days under similar culture conditions to generate pre-cultures in three bottles for each species. The cells were harvested and used for the mixing of the two species on day 2 after inoculation. This date corresponded to the exponential phase of growth, which was determined by assessing the cell density. The mixing ratios based on total cell volume of $P$. micans and $P$. minimum were assumed as follows. The five different mixing proportions of $P$. minimum were set at $0 \%$ (mixing experiment 1 ), $25 \%$ (mixing experiment 2 ), $50 \%$ (mixing experiment 3 ), $75 \%$ (mixing experiment 4 ), and $100 \%$ (mixing experiment 5), using a similar total cell density of the sum of two populations. Since the chl $a$ concentration is significantly associated with cell volume in laboratory cultures, the total chl $a$ concentration $(C)$ was calculated as the sum of the concentrations of $C_{\min }$ and $C_{\text {mic }}$ of the two populations,

$$
C=C_{\text {min }}+C_{\text {mic }}
$$

where $C_{\min }$ and $C_{\text {mic }}$ are the chl $a$ concentrations (mg chl $a \mathrm{~m}^{-3}$ ) of the two phytoplankton populations (P. minimum and $P$. micans) with different cell sizes. Therefore, a total absorption of coefficient $\left(\mathrm{m}^{-1}\right)$ due to summation of the two species, $a_{\mathrm{ph}}(\lambda)$ can be determined as,

$$
a_{\mathrm{ph}}(\lambda)=a_{\text {min }}^{*}(\lambda) C_{\text {min }}+a_{\text {mic }}^{*}(\lambda) C_{\text {mic }}
$$

where $a_{\text {min }}^{*}(\lambda)$ and $a_{\text {mic }}^{*}(\lambda)$ are the specific absorption coefficients $\left(\mathrm{m}^{2}[\mathrm{mg} \mathrm{chl} a]^{-1}\right)$ of the two phytoplankton populations ( $P$. minimum and P. micans) with different cell sizes, respectively.

\section{Cell density}

The cells in each $20-\mathrm{mL}$ subsample were centrifuged at a constant speed of 4,000 rpm for ten minutes. The supernatant was discarded, and the sedimented pellets were resuspended in $2.5-\mathrm{mL}$ tubes with fresh filtered sea water. Then, the samples were centrifuged again at a constant speed of $10,000 \mathrm{rpm}$ for five minutes and concentrated to $0.20 \mathrm{~mL}$. The cell density of each subsample was measured on an inverted microscope (Olympus, IMT-2, Japan) at $100 \times$ magnification using a hemocytometer (Erma Inc. Japan).

\section{Growth rate}

The growth rate $\left[\mu\left(\mathrm{d}^{-1}\right)\right]$ was calculated from the cell density using the following equation (Guillard 1973):

$$
\mu=\ln \left(N_{t} / N_{0}\right) /\left(t_{1}-t_{0}\right)
$$

where $N_{\mathrm{t}}$ and $N_{0}$ are the cell density in cells $\mathrm{mL}^{-1}$ at the beginning $\left(t_{0}\right)$ and end $\left(t_{1}\right)$ of the exponential phase, respectively.

\section{Cell volume}

It is crucial to estimate the cell volume in a study of light absorption, therefore, the shape of Prorocentrum micans and Prorocentrum minimum was assumed as ellipsoid. The length $(l)$, width $(w)$, and height $(h)$ of 30-50 cells per sample were measured using a micrometer with an ocular ruler at $400 \times$ magnification under a compound microscope (Olympus, CH-2, Japan). The cell volume was calculated using the equation for an ellipsoid described by Hillebrand et al. (1999):

$$
\mathrm{V}=4 \pi l w h / 3
$$

Equivalent spherical diameter (ESD) was calculated from the estimated cell volume.

\section{Pigments}

Subsamples for intracellular pigment analyses (10$20 \mathrm{~mL}$ ) were filtered onto $25 \mathrm{~mm} \mathrm{GF} / \mathrm{F}$ glass fiber filters (Whatman, USA) and preserved in the dark at $-80^{\circ} \mathrm{C}$ until analysis. The filtered samples were fragmented using an ultrasonic disintegrator (SMT, Japan) with $2 \mathrm{~mL}$ of $90 \%$ acetone, after which the pigments on the filter were extracted for $24 \mathrm{~h}$ in the dark at $-20^{\circ} \mathrm{C}$. The extracted liquids were filtered through a filter with a pore size of $0.2 \mu \mathrm{m}$ (Millex, Millipore, Germany). Subsequently, the filtered extracts were assayed via high-performance liquid chro- 
matography (HPLC, Beckman, USA: 168 Diode Array Detector, CI8 reversed phase Ultrasphere $3-\mu \mathrm{m}$ column) using a solvent gradient system described by Head \& Horne (1993). Integrated HPLC peak areas were quantified using standards for chlorophyll $a$ (chl $a)$, chlorophyll $c(\mathrm{chl} c)$, peridinin (perid), diadinoxanthin (DD), diatoxanthin (DT), and $\beta$-carotene ( $\beta$-Caro) obtained from the International Agency for $14 \mathrm{C}$ determination.

\section{Light absorption}

Subsamples for light absorption determinations (10$20 \mathrm{~mL}$ ) were filtered onto $25-\mathrm{mm}$ GF/F glass fiber filters (Whatman, USA) and preserved in the dark at $-80^{\circ} \mathrm{C}$ until analysis (Sosik 1999). Light absorption was measured using a dual beam UV-Vis spectrophotometer (Shimadzu, UV-2450, Japan) following the quantitative filtered technique (QFT) method described by Mitchell \& Kiefer (1988). A blank filter that was wetted with filtered seawater was used as a reference. Absorption spectra were recorded every $\mathrm{nm}$ from $250-800 \mathrm{~nm}$. The absorption spectra were corrected by the average optical density at $730-760 \mathrm{~nm}$ (Babin \& Stramski 2002). For the conversion of the corrected optical density of the filtered total particles $\left(O D_{\mathrm{f}}\right)$ to the particles in suspension $\left(O D_{\mathrm{s}}\right)$, the following general equation was used (Cleveland \& Weideman 1993):

$$
O D_{\mathrm{s}}(\lambda)=0.378 O D_{\mathrm{f}}(\lambda)+0.523\left(O D_{\mathrm{f}}[\lambda]\right)^{2}
$$

The optical density of the suspension $\left(O D_{\mathrm{s}}\right)$ was transformed into the absorption coefficient of particles in sample $\left(a_{\mathrm{p}}\right)$ using the following equation:

$$
a_{\mathrm{p}}(\lambda)=2.303 O D_{\mathrm{s}}(\lambda) S V^{-1}
$$

where 2.303 converts from decimal to natural logarithm, $S$ is the filtered clearance area and $V$ is the filtered volume. After taking $O D_{\mathrm{f}}$ measurements, the pigments on the filter were extracted with $100 \%$ methanol for $24 \mathrm{~h}$ (Kishino et al. 1985). Then, the de-colorized filters were moistened with filtered sea water and the optical density of the nonpigmented particles $\left(a_{\mathrm{d}}\right)$ was measured using a spectrophotometer (Shimadzu, UV-2450, Japan). The absorption coefficients of detritus were calculated from the $O D_{\mathrm{f}}$ values of the de-colorized filter. The difference between the $a_{\mathrm{d}}$ and $a_{\mathrm{p}}$ values was considered to be the light absorption coefficient of phytoplankton $\left(a_{\mathrm{ph}}\right)$,

$$
a_{\mathrm{ph}}(\lambda)=a_{\mathrm{p}}(\lambda)-a_{\mathrm{d}}(\lambda)
$$

Finally, $a_{\mathrm{ph}}$ was converted to chl $a$ specific absorption coefficient $\left(a_{\mathrm{ph}}^{*} ; \mathrm{m}^{2}[\mathrm{mg} \mathrm{chl} a]^{-1}\right)$ by dividing the $a_{\mathrm{ph}}$ value by the concentration of $\operatorname{chl} a\left(\mathrm{mg} \operatorname{chl} a \mathrm{~m}^{-3}\right)$,

$$
a_{\mathrm{ph}}^{*}(\lambda)=a_{\mathrm{ph}}(\lambda) / \operatorname{chl} a
$$

The spectral average chl $a$ specific absorption coefficient $\left[\bar{a}_{\mathrm{ph}}^{*}(\lambda)\right]$ was calculated by integrating the absorption wavelengths measured from $400-700 \mathrm{~nm}$ and dividing by the number of wavelengths measured:

$$
\bar{a}_{\mathrm{ph}}^{*}(\lambda)=\frac{\int_{400}^{700} a_{\mathrm{ph}}^{*}(\lambda) d(\lambda)}{\int_{400}^{700} d(\lambda)}
$$

The absorption spectra of cells $\left[a_{\mathrm{ph}}^{\prime}(\lambda)\right]$ were reconstructed at 2-nm intervals from $400-750 \mathrm{~nm}$ using the method described by Bidigare et al. (1990) and calculated using the following equation:

$$
a_{\mathrm{ph}}^{\prime}(\lambda)=\sum_{i=1}^{n} C_{\mathrm{i}} a_{\mathrm{i}}^{*}(\lambda)
$$

where $C_{\mathrm{i}}$ is the HPLC-determined concentration of pigment group $i$ at the mixing ratios in the mixing experiments $\left(\mathrm{mg} \mathrm{m}^{-3}\right)$ and $a_{\mathrm{i}}^{*}(\lambda)$ is the specific absorption coefficient of pigment group $i$ at wavelength $\lambda\left(\mathrm{m}^{2} \mathrm{mg}^{-1}\right)$.

The homogeneity of the cells should be considered as uniformly packed by pigments (Morel \& Bricaud 1981). Large cells contain large amounts of photosynthetic pigments and are subject to the "package effect" (Berner et al. 1989). The absorption efficiency of cell $i$ at a given wavelength $\left[a_{\mathrm{ph}}(\lambda)\right]$ in a suspension with a specific number of cells $(N)$ for a suspension with a specific volume $(V)$ is approximated by the following equation (11),

$$
a_{\mathrm{ph}}(\lambda)=\frac{1}{V} \sum_{i=1}^{N} Q_{\mathrm{a}}(\lambda) \mathrm{iGi}
$$

where $Q_{\mathrm{a}}(\lambda)_{\mathrm{i}}$ is the absorption efficiency for a cell $i$ at wavelength $(\lambda)$ (Bricaud et al. 1983) and $G_{\mathrm{i}}$ is the geometric cross-sectional area of cell $i$ (Iturriaga \& Siegel 1989). The fractional reduction of pigment absorption due to the package effect $\left[Q_{\mathrm{a}}^{*}(\lambda)\right]$ can be calculated for a given wavelength as the quotient of $a_{\mathrm{ph}}(\lambda)$ and $a_{\mathrm{ph}}^{\prime}(\lambda)$ using the following equation (12) (Nelson \& Prezelin 1990),

$$
Q_{\mathrm{a}}^{*}(\lambda)=\frac{a \mathrm{ph}(\lambda)}{a \operatorname{ph}^{\prime}(\lambda)}
$$

Simultaneously, the $a_{\mathrm{ph}}^{\prime}(\lambda)$ can be obtained from the $a_{\mathrm{ph}}(\lambda)$ of the ethanol extraction (Jeffery et al. 2011, Fujiki \& Taguchi 2002).

\section{Statistical analysis}

Statistical differences in the variables at a given wavelength between treatments were analyzed using an ANOVA.

\section{Results}

\section{Cell density and volume}

The experimental cells used in this study were prepared from rapidly growing Prorocentrum micans $\left(0.30 \mathrm{~d}^{-1}\right)$ and Prorocentrum minimum $\left(0.45 \mathrm{~d}^{-1}\right)$. When the cell density of $P$. micans and $P$. minimum on day 2 reached a similar density, $4.52 \pm 0.595$ and $4.507 \pm 0.542 \times 10^{6}$ cells $\mathrm{mL}^{-1}$, respectively (Fig. 1A), the cell volume of $P$. micans $\left(41.1 \pm 4.6 \times 10^{6} \mu \mathrm{m}^{3} \mathrm{~mL}^{-1}\right)$ was approximately 8 -fold great- 
er than that of $P$. minimum $\left(4.89 \pm 0.75 \times 10^{6} \mu \mathrm{m}^{3} \mathrm{~mL}^{-1}\right)$ (Fig. 1B), resulting in a 2-fold difference in the ESD (Fig. 1C). The mixing ratios of $P$. minimum based on the cell volume were $0 \%$ (mixing experiment 1 ), $23 \pm 2 \%$ (mixing experiment 2 ), $48 \pm 5 \%$ (mixing experiment 3 ), $75 \pm 4 \%$ (mixing experiment 4 ), and $100 \%$ (mixing experiment 5 ).

\section{Pigments}

Six pigments (Chl $a$, chl $c$, perid, DD $+\mathrm{DT}$, and $\beta$-caro) were detected from Prorocentrum micans and Prorocentrum minimum. The chl $a$ content per cell $(10.3 \pm 2.56 \mathrm{pg}$ cell $^{-1}$ ) of $P$. micans was approximately 4.0 -fold higher than that of $P$. minimum $\left(2.56 \pm 0.30 \mathrm{pg}\right.$ cell $\left.^{-1}\right)$, while the
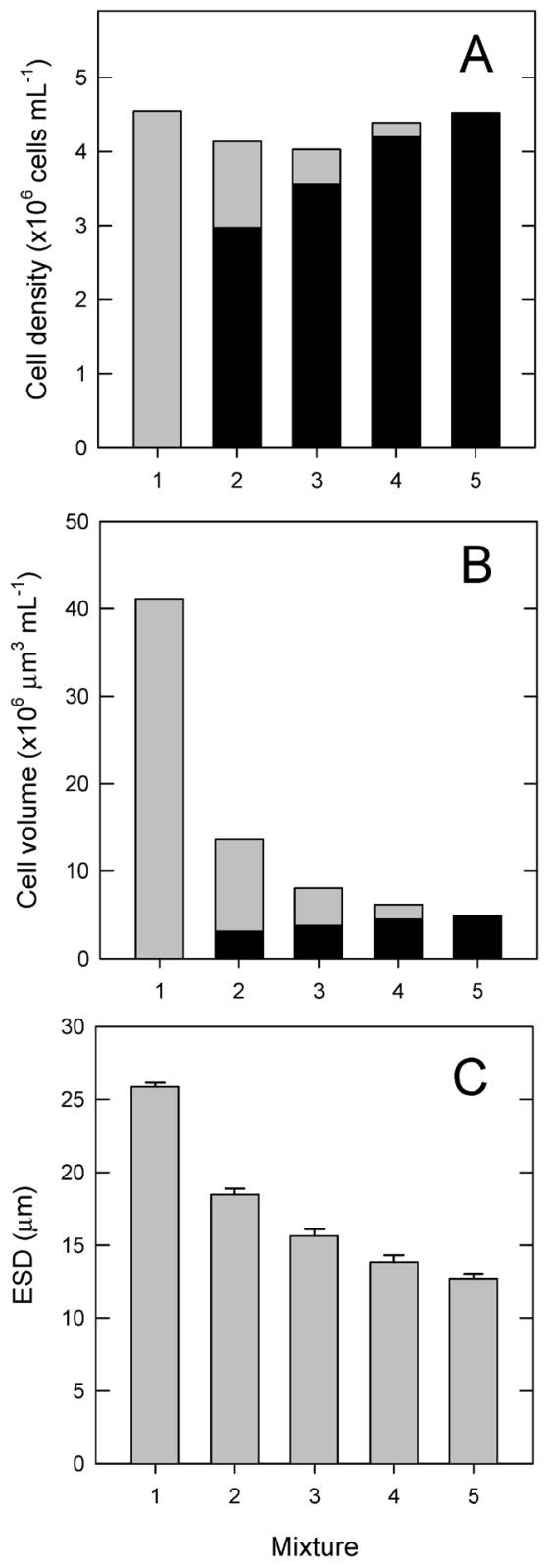

Fig. 1. Total cell density (A), cell volume (B), and ESD (C) in 5 mixtures of Prorocentrum micans (gray bar) and Prorocentrum minimum (black bar). total pigment content of $P$. micans $\left(21.6 \pm 2.1 \mathrm{pg} \mathrm{cell}^{-1}\right)$ was approximately 3.5 -fold greater than that of $P$. minimum $\left(6.26 \pm 0.53 \mathrm{pg} \mathrm{cell}^{-1}\right)$. The (total and chl a) pigment content per cell $\left(5.82 \pm 0.76\right.$ and $\left.2.39 \pm 0.37 \mathrm{~kg} \mathrm{~m}^{-3}\right)$ for $P$. minimum were approximately 2.1- and 2.4-fold higher than those observed for $P$. micans $\left(2.38 \pm 0.31\right.$ and $\left.1.14 \pm 0.13 \mathrm{~kg} \mathrm{~m}^{-3}\right)$, respectively (Fig. 2). The relative abundance of (total and chl a) pigment content per cell $\left[C_{\mathrm{i}}\left(\mathrm{kg} \mathrm{m}^{-3}\right)\right]$ for P. micans and $P$. minimum were not significantly different between the different mixing ratios. The photosynthetic pigments (chl $a$ and $\operatorname{chl} c$ ) accounted for $56.6-59.4 \%$ of total cellular pigments. The accessory pigments (perid) accounted for $22.4-28.5 \%$ of cellular total pigments, while the other photoprotective pigments (DD+DT and $\beta$-caro) accounted for $13.7-19.4 \%$ of the pigment content per cell (Fig. 2).

\section{Light absorption}

The absorption spectrum $\left[a_{\mathrm{ph}}(\lambda)\right]$ of Prorocentrum micans and Prorocentrum minimum showed two absorption maxima at approximately 440 and $676 \mathrm{~nm}$ and decreased with mixing (Fig. 3A). There was a slight difference in the absorption spectrum between 400 and $460 \mathrm{~nm}$, i.e., the absorption in P. minimum was lower than that in P. micans. The highest absorption was observed for mixing experiment 1 , whereas the lowest absorption was observed for mixing experiment 5 (Fig. 3B). However, the $a_{\mathrm{ph}}^{*}$ value was not significantly different between the five mixing ratios assayed in this study (Fig. 3C). The $a_{\text {ph }}(\lambda)$ values at 9 wavelengths $(412,440,480,510,532,555,650,676$, and $700 \mathrm{~nm}$ ) were significantly associated with cell volume $\left(\mu \mathrm{m}^{3} \mathrm{~mL}^{-1}\right)$ (Fig. $\left.4 \mathrm{~A}\right)$, chl $a$ concentration $\left(\mathrm{mg} \mathrm{m}^{-3}\right)$ (Fig. 4B), and intracellular pigment content, $C_{\mathrm{i}}\left(\mathrm{kg} \mathrm{m}^{-3}\right)$ (Fig. 4C).

Spectrally reconstructed absorption spectra from HPLC-determined pigment concentrations $\left[a_{\mathrm{ph}}^{\prime}(\lambda)\right]$ and measured in vivo absorption spectra $\left[a_{\mathrm{ph}}(\lambda)\right]$ ranged from the highest values at $440 \mathrm{~nm}$ to the lowest values at $700 \mathrm{~nm}$

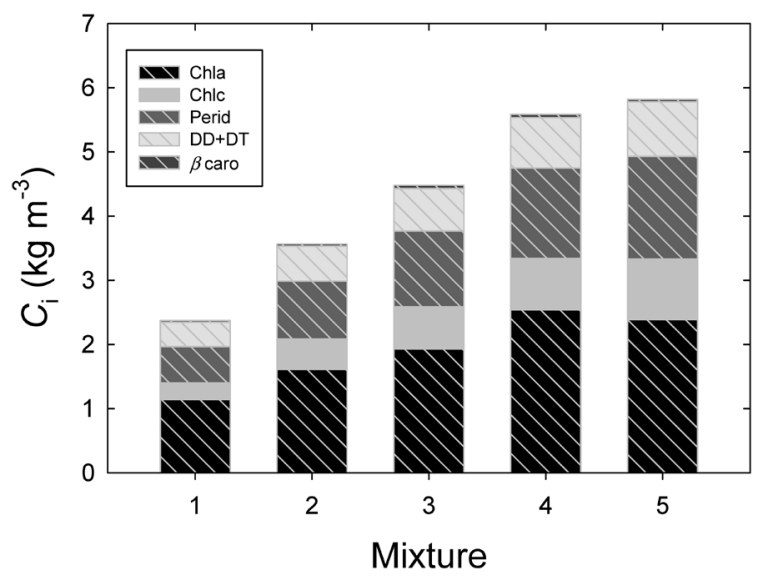

Fig. 2. Abundances of chl $a$, chl $c$, perid, DD+DT, and $\beta$-caro in Prorocentrum micans and Prorocentrum minimum based on intracellular pigment contents $\left(C_{\mathrm{i}}\right)$ in 5 mixtures of $P$. micans and P. minimum. 
in the five mixing ratios. Prorocentrum micans alone exhibited the highest values, whereas $P$. minimum alone exhibited the lowest values in all mixing combinations. The $Q_{\mathrm{a}}^{*}(\lambda)$ values were lower than unity at all mixing ratios assayed, indicating an overestimation of absorption spectra
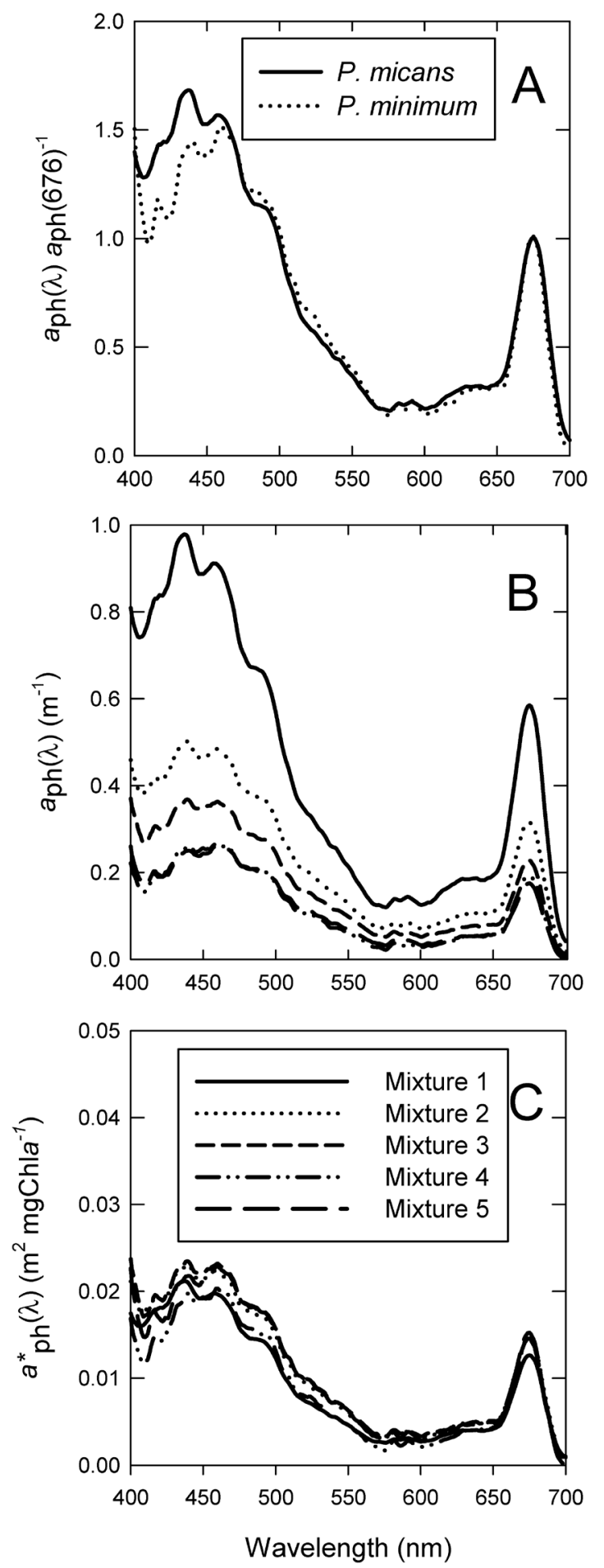

Fig. 3. Normalized light absorption of cells $\left(a_{\mathrm{ph}}\right)$ at $676 \mathrm{~nm}(\mathrm{~A})$, light absorption $\left[a_{\mathrm{ph}}(\lambda)\right](\mathrm{B})$, and chl $a$ specific absorption $\left[a_{\mathrm{ph}}^{*}(\lambda)\right]$ (C) in 5 mixtures of Prorocentrum micans and Prorocentrum minimum. by reconstruction and resulting in the package effect at the 9 wavelengths, although the values were highly variable (Fig. 5A). The fractional reduction in the pigment absorption due to $Q_{\mathrm{a}}^{*}(\lambda)$ exhibited a significant relationship with the 9 measured wavelengths ( $p<0.01$, Fig. 5B). The smallest package effects were observed at $676 \mathrm{~nm}$, whereas the largest effects were observed at $440 \mathrm{~nm}$.

\section{Discussion}

The non-sphericity of many phytoplankton cells has been well documented (Jonasz 1987). However, spherical approximations have often been used in field studies (e.g. Nelson et al. 1993) despite there being little detailed information on the shapes of cells in the samples. General meth-
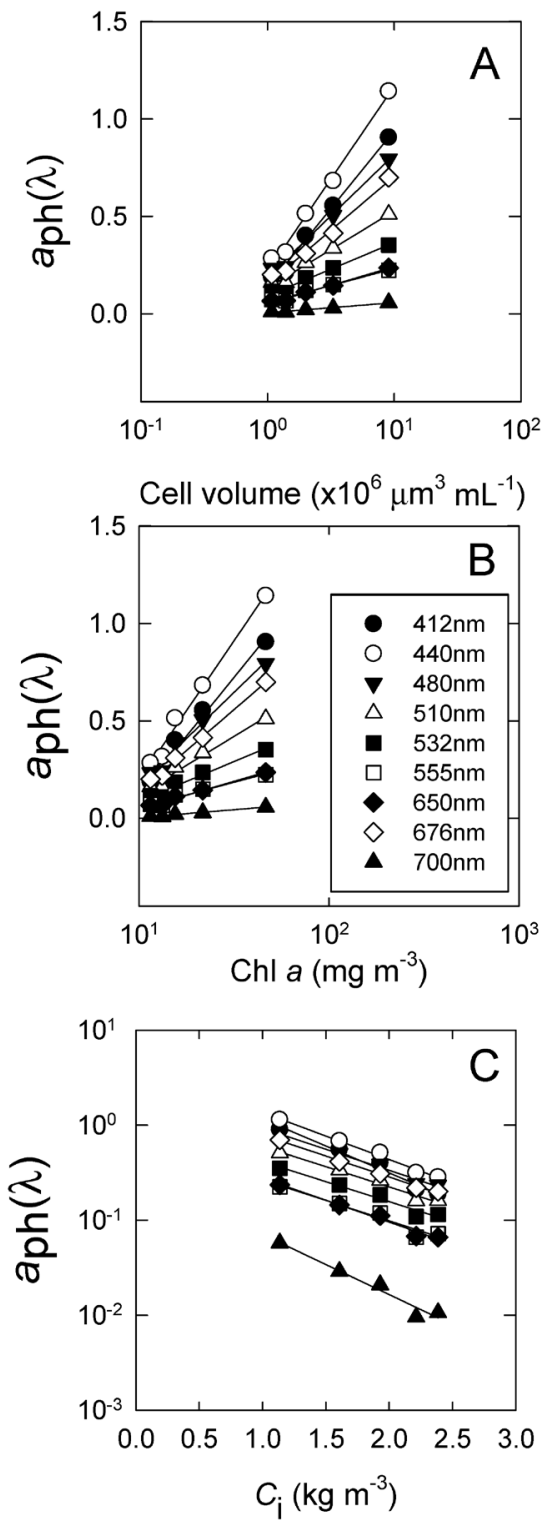

Fig. 4. Light absorption $\left[a_{\mathrm{ph}}(\lambda)\right]$ at $412,440,480,510,532$, $555,650,676$, and $700 \mathrm{~nm}$ versus total cell volume (A), chl $a$ concentrations (B), and intracellular chl $a$ contents (C). 
ods used to calculate the absorption properties of various shapes of cells have been developed by Kirk (1976). The spherical approximation method has proved to be satisfactory for cultures covering a wide variety of phytoplankton taxa (More1 \& Bricaud 1981, Sathyendranath et al. 1987, Bricaud et al. 1988, Nelson \& Prezelin 1990, Nelson et al. 1993), and the homogeneity of microalgal cells is ubiquitously determined among chronological groups (Jeffrey et al. 2011).

The light absorption of an algal population $\left[a_{\mathrm{ph}}(\lambda)\right]$ varies with cell size, although they have similar pigment concentrations (Morel \& Bricaud 1981). Increasing cell volume facilitates pigment self-shading and a decrease in $a_{\mathrm{ph}}^{*}$, which is estimated using the intracellular chl $a$ contents (Kirk 1976, Finkel 2001). However, the $a_{\mathrm{ph}}^{*}$ value at a given wavelength was not significantly different between the five mixing ratios assayed in this study. When the proportion of large cells was increased, the packaging effect caused by the cell volume may facilitate a decrease in $a_{\mathrm{ph}}^{*}$. In the present study, opposite trends in the relationship between cell volume or $C_{\mathrm{i}}$ values and the mixing ratios may cancel the package effect. Due to a combination of these two vari-
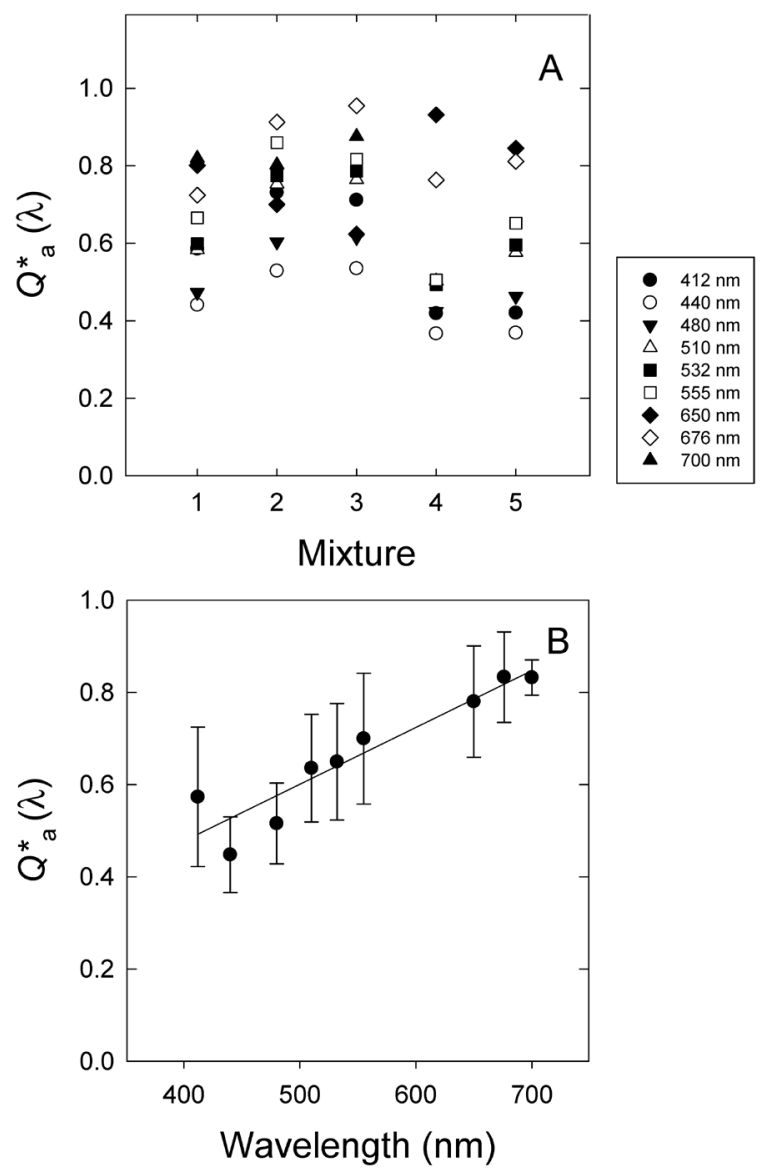

Fig. 5. Light absorption efficiency $\left[Q_{\mathrm{a}}^{*}(\lambda)\right]$ at $412,440,480$, $510,532,555,650,676$, and $700 \mathrm{~nm}$ for the 5 mixtures of Prorocentrum micans and Prorocentrum minimum (A) and wavelength (B). ables, the observed $a_{\mathrm{ph}}^{*}$ did not indicate significantly different effects in the mixing ratios used for the two species, e.g., $0.0112 \pm 0.0006$ and $0.0122 \pm 0.0023 \mathrm{~m}^{2}(\mathrm{mg} \mathrm{chl} a)^{-1}$, for Prorocentrum micans and Prorocentrum minimum alone, respectively. The results of the present study do not indicate any significant change in the $a_{\mathrm{ph}}^{*}$ value within the $E S D$ size range evaluated in this study (Fig. 1C).

However, as wider ranges of cell sizes occur in situ in the ocean, the relationship between cell volume and the $a_{\mathrm{ph}}^{*}$ value can be affected by the pigment content per unit cell volume and pigment composition (Kirk 1975, Morel $\&$ Bricaud 1981). When light absorption of chl $a\left[a_{\mathrm{ph}}^{*}(676)\right]$ is compared with previously published data (Fujiki \& Taguchi 2002, Leong \& Taguchi 2006), it is significantly related to $E S D^{*} C_{\mathrm{i}}(p<0.01$, Fig. $6 \mathrm{~A})$. The estimates obtained in the present study are observed at the far-left end of the regression line because of the relatively large size of the studied cells compared to those in other studies (Fujiki \& Taguchi 2002, Leong \& Taguchi 2006). The spectral package effect of $\left(Q_{\mathrm{a}}^{*}\right)$ at $676 \mathrm{~nm}$, based on the same sets of data shown in Fig. 6A, are significantly correlated with $E S D^{*} C_{\mathrm{i}}(p<0.01$, Fig. $6 \mathrm{~B})$, suggesting lower package effects at smaller $E S D^{*} C_{\mathrm{i}}$ values. However, this result sug-
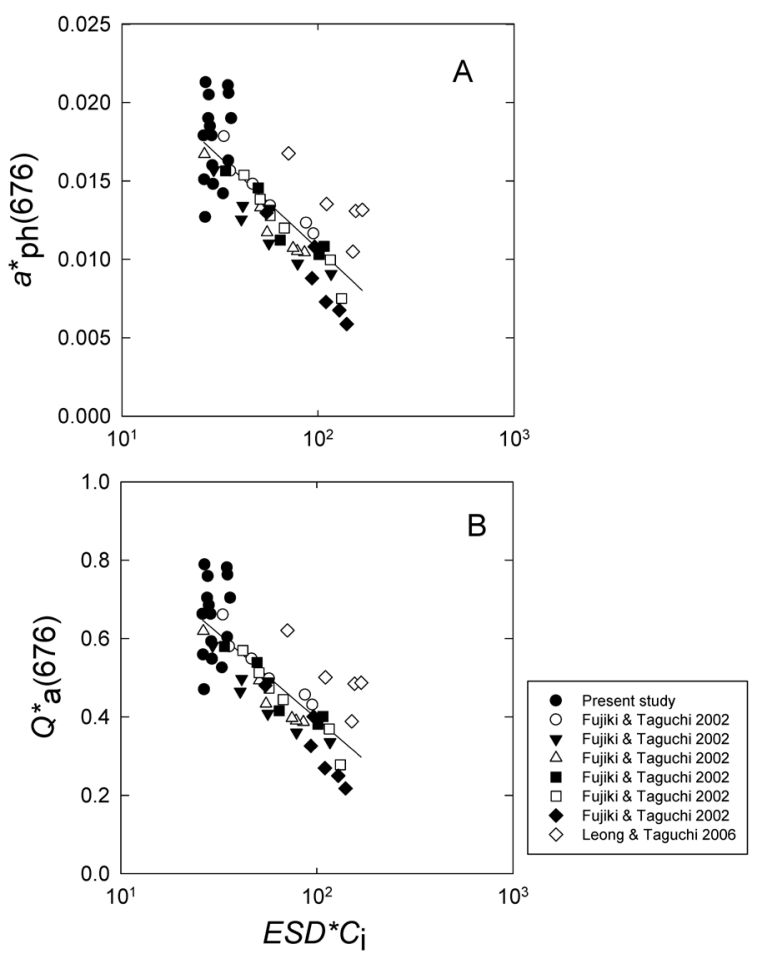

Fig. 6. Relationship between light absorption $\left[\mathrm{a}_{\mathrm{ph}}^{*}(676)\right]$ (A) or light absorption efficiency $\left[Q_{\mathrm{a}}^{*}(676)\right]$ and $E S D^{*} C_{\mathrm{i}}(\mathrm{B})$. The open circle, reversed closed triangle, open triangle, closed square, open square, and closed diamond represent Isochrysis galbana, Pleurochrysis carterae, Chaetoceros gracilis, Dunaliella tertiolecta, Thalassiosira weisflogii, and Coscinodiscus sp., respectively (Fujiki \& Taguchi 2002). The open diamond represents Alexandria tamarense (Leong \& Taguchi 2006), and the closed circle represents the present study. 
gests that most estimates of $a_{\mathrm{ph}}^{*}$ are subject to the package effect, particularly in coastal waters. Cell volume should be considered for quantitative studies on the relationship between cell size and spectral light absorption. One possible application of the present study would involve intensive HPLC profiling, which provides chl $a$ specific absorption, $a_{\mathrm{ph}}^{*}$ and size distribution (Brewin et al. 2011), combined with direct measurements of phytoplankton absorption using QFT methods (Mitchell \& Kiefer 1988) or in situ spectrophotometry (Johnsen et al. 1994) to estimate the spectral $Q_{\mathrm{a}}^{*}(\lambda)$. This approach would allow for correctly reconstructed spectra to be obtained for use in modeling absorption-based bio-optical productivity models in the ocean, although some models are successfully employed without using the absorption (e.g., Siegel et al. 1989). In particular, the addition of information on the package effect would improve current models.

Prorocentrum minimum and $P$. micans are primarily observed in coastal waters in temperate and tropical regions (Kimor et al. 1985, Smayda 1990, Grzebyk et al. 1997) blooming together and consistently being present in the late summer and fall (Horner 2002, Kraberg et al. 2010) in lit, shallow surface waters (Kimor et al. 1985). However, they occasionally reach higher than $30 \mathrm{mg}$ chl $a \mathrm{~m}^{-3}$ at the subsurface chlorophyll maximum (Pingree et al. 1982). Under field conditions, both species show a lower package effect than other groups of phytoplankton as the $Q_{\mathrm{a}}^{*}(676)$ of the two species is larger than approximately 0.5 , as shown in the present study.

\section{Acknowledgements}

This research was supported in part by NASDA grants (ST). We thank T. Fujiki and S. Leong for providing HPLC pigment data. Constructive comments on an early version of the manuscript provided by T. Fujiki were greatly appreciated. The authors would like to appreciate two anonymous reviewers for the improvement of the present manuscript.

\section{References}

Babin M, Legendre L, Condal A (1993) Variation in the specific absorption coefficient for natural phytoplankton assemblages: Impact on estimates of primary production. Limnol Oceanogr 38: 154-177.

Babin M, Stramski D (2002) Light absorption by aquatic particles in the near-infrared spectral region. Limnol Oceanogr 47: 911-915.

Behrenfeld M J, \& Falkowski P G (1997) Photosynthetic rates derived from satellite-based chlorophyll concentration. Limnol Oceanogr 42: 1-20.

Berner T Z, Dubinsky Z, Wyman K, Falkowski P G (1989) Photoadaptation and the "package effect" in Dunaliella tertiolecta (Chlorophyceae). J Phycol 25: 70-78.

Bidigare R R, Ondrusek M E, Morrow J H, Kiefer D A (1990)
In vivo absorption properties of algal pigments. In: Spinrad RW, Ocean Optics X, Proc Soc Photo-optical Inst Eng 1302: 90-302.

Brewin R J W, Hardman-Mountford N J, Lavender S J, Raitsos D E, Hirata T, Uitz J, Devred E, Bricaud A, Ciotili B (2011) An intercomparison of bio-optical techniques for detecting dominant phytoplankton size class from satellite remote sensing. Remote Sens Environ 115: 325-339.

Bricaud A, Bedhomme A L, Morel A (1988) Optical properties of diverse phytoplanktonic species, experimental results and theoretical interpretation. J Plankton Res 10: 851-873.

Bricaud A, Morel A, Prieur L (1983) Optical efficiency factors of some phytoplankters. Limnol Oceanogr 28: 816-832.

Bricaud A, Stramski D (1990) Spectral absorption coefficients of living phytoplankton and nonalgal biogenous matter: A comparison between the Peru upwelling area and the Sargasso Sea. Limnol Oceanogr 35: 562-582.

Ciotti A M, Lewis M R, Cullen J J (2002) Assessment of the relationships between dominant cell size in natural phytoplankton communities and the spectral shape of the absorption coefficient. Limnol Oceanogr 47: 404-417.

Cleveland J S, Weideman A D (1993) Quantifying absorption by aquatic particles: A multiple scattering correction for glassfiber filters. Limnol Oceanogr 38: 1321-1327.

Devred E, Sathyendranath S, Stuart V, Maass H, Ulloa O, Platt T (2006) A two-component model of phytoplankton absorption in the open ocean: Theory and applications. J Geophy Res 111, C03011, doi: 10.1029/2005JC002880.

Finkel Z V (2001) Light absorption and size scaling of lightlimited metabolism in marine diatoms. Limnol Oceanogr 46: 86-94.

Fujiki T, Taguchi S (2002) Variability in chlorophyll $a$ specific absorption coefficient in marine phytoplankton as a function of cell size and irradiance. J Plankton Res 24: 859-874.

Grzebyk D, Denardou A, Berland B, Pouchus Y. F (1997) Evidence of a new toxin in the red-tide dinoflagellate Prorocentrum minimum. J Plankton Res 19: 1111-1124.

Guillard R R L (1973) Division rates. In Stein J R (ed.), Handbook of phycological methods. Cambridge University Press, New York, pp. 289-311.

Guillard R R L, Ryther J H (1962) Studies of the marine planktonic diatoms. 1. Cyclotella nana Hustedt and Detonula conferbaceae (Cleave.) Gran. Can J Microbiol, 8: 229-239.

Head E J H, Horne E P W (1993) Pigment transformation and vertical flux in an area of convergence in the North Atlantic. Deep-Sea Res 40: 329-346.

Hillebrand H, Durselen C D, Kirschtel D, Pollingher U, Zohary $\mathrm{T}$ (1999) Biovolume calculation for pelagic and benthic microalgae. J Phycol 35: 409-424.

Horner R A (2002) A taxonomic guide to some common phytoplankton. Biopress Limited, Dorset Press, Dorchester, U.K. pp. 200.

Iturriaga R, Siegel D A (1989) Microphotometric characterization of phytoplankton and detrital absorption properties in the Sargasso Sea. Limnol Oceanogr 34: 1706-1726.

Jeffrey S W, Wright S, Zapata M (2011) Microalgal classes and their signature pigments, pp. 3-77. In Roy S, Llewellyn C, Egeland E, Johnsen G [eds.], Phytoplankton Pigments: Charac- 
terization, Chemotaxonomy and Application in Oceanography. Cambridge Environmental Chemistry Series, Cambridge University Press.

Johnsen G, Samset O, Granskog L, Saksaug E (1994) In vivo absorption characteristics in 10 classes of bloom-forming phytoplankton: taxonomic characteristics and responses to photoadaptation by means of discriminant and HPLC analysis. Mar Ecol Prog Ser 105: 149-157.

Jonasz M (1987) Nonsphericity of marine particles and its influence on light scattering. Limnol Oceanogr 32: 1059-1065.

Kimor B, Moigis A G, Dohms V, Stienen C (1985) A case of mass occurrence of Prorocentrum minimum in the Kiel Fjord. Mar Ecol Prog Ser 27: 209-215.

Kirk J T O (1975) A theoretical analysis of the contribution of algal cells to the attenuation of light within natural waters. II. Spherical cells. New Phytol 75: 21-36.

Kirk J T O (1976) A theoretical analysis of the contribution of algal cells to the attenuation of light within natural waters. III. Cylindrical and spheroidal cells. New Phytol 11: 341-358.

Kirk J T O (1994) Light and Photosynthesis in Aquatic Ecosystems. Cambridge University Press, Cambridge.

Kishino M, Takahashi M, Okami N, Ichimura S (1985) Estimation of the spectral absorption coefficients of phytoplankton in the sea. Bull Mar Sci 37: 634-642.

Kraberg A, Baumann M, Durselen C D (2010) Coastal phytoplankton photo guide for Northern European Seas. Verlag, Munchen, Germany pp. 203.

Leong S C Y, Taguchi S (2006) Detecting the bloom-forming dinoflagellate Alexandrium tamarense using the absorption signature. Hydrobiol 568: 299-308.

Longhurst A, Sathyendranath S, Platt T, Caverhill C (1995) An estimate of global primary production in the ocean from satellite radiometer data. J Plankton Res 17: 1244-1271.

Lutz V A, Sathyendranath S, Head E J H, Li W K W (2001) Change in the in vivo absorption and fluorescence excitation spectra with growth irradiance in three species of phytoplankton. J Plankton Res 23: 555-569.

McClain C R, Feldman G C, Hooker S B (2003) An overview of the SeaWiFS project and strategies for producing a climate research quality global ocean bio-optical time series. Deep-Sea Res II 51: 5-42.
Mitchell B G, Kiefer D A (1988) Chlorophyll a specific absorption and fluorescence excitation spectra for light-limited phytoplankton. Deep-Sea Res 35: 639-663.

Morel A, Bricaud A (1981) Theoretical results concerning light absorption in a discrete medium, and application to specific absorption of phytoplankton. Deep-Sea Res 28: 1375-1393.

Nelson N B, Prezelin B B (1990) Chromatic light effects and physiological modeling of absorption properties of Heterocapsa pygmaea (= Glenodinium sp.) Mar Ecol Prog Ser 63: 37-46.

Nelson N B, Prezelin B B, Bidigare R R (1993) Phytoplankton light absorption and the package effect in California coastal waters. Mar Ecol Prog Ser 94: 217-227.

Pingree R D, Holligan P M, Mardelli G T, Harris R P (1982) Vertical distribution of plankton in the Skagerrak in relation to doming of the seasonal thermocline. Cont Shelf Res 1: 209219.

Sathyendranath S, Lazzara L, Prieur L (1987) Variations in the spectral values of specific absorption of phytoplankton. Limnol Oceanogr 32: 403-415.

Schofield O, Prezelin B B, Stegmann P, Nelson N B, Lewis M R (1991) Variability in spectral and nonspectral measurements of photosynthetic light utilization efficiencies. Mar Ecol Prog Ser 78: 253-271.

Siegel D A, Westberry T K, O'Brien1 M C, Nelson N B, Michaels A F, Morrison J R, Smith R C, Prezelin B B, Bidigare R R, Baker K S (1989) Bio-optical modeling of photosynthetic production in coastal waters. Limnol Oceanogr 34: 1524-1544.

Smayda T J (1990) Novel and nuisance phytoplankton blooms in the sea: evidence for a global epidemic. In, Graneli E, Sundstrom B, Edler L, Anderson D M (eds.), Toxic Marine Phytoplankton. Elsevier, New York, pp. 29-40.

Sosik H M (1999) Storage of marine particulate samples for light-absorption measurements. Limnol Oceanogr 44: 11391141.

Sosik M H, Mitchell B G (1991) Absorption, fluorescent, and quantum yield for growth in nitrogen-limited Dunaliella tertiolecta. Limnol Oceanogr 36: 910-921.

Yentsch C S (1989) A bridge between ocean optics and microbial ecology. Limnol Oceanogr 34: 1694-1705. 